\title{
Student Content Knowledge Increases After Participation in a Hands-on Biotechnology Intervention
}

Amber L. Bigler

Brigham Young University - Provo

Follow this and additional works at: https://scholarsarchive.byu.edu/etd

Part of the Biology Commons

\section{BYU ScholarsArchive Citation}

Bigler, Amber L., "Student Content Knowledge Increases After Participation in a Hands-on Biotechnology Intervention" (2010). Theses and Dissertations. 2522.

https://scholarsarchive.byu.edu/etd/2522

This Thesis is brought to you for free and open access by BYU ScholarsArchive. It has been accepted for inclusion in Theses and Dissertations by an authorized administrator of BYU ScholarsArchive. For more information, please contact scholarsarchive@byu.edu, ellen_amatangelo@byu.edu. 
Student Content Knowledge Increases After Participation in a

Hands-on Biotechnology Intervention

Amber L. Bigler

A thesis submitted to the faculty of

Brigham Young University

in partial fulfillment of the requirements for the degree of

Master of Science

in Biological Science Education

Nikki L. Hanegan, Chair

Byron Adams

Joshua Udall

Department of Biology

Brigham Young University

August 2010

Copyright (C) 2010 Amber L. Bigler

All Rights Reserved 


\begin{abstract}
Student Content Knowledge Increases After Participation in a

Hands-on Biotechnology Intervention
\end{abstract}

Amber L. Bigler

Department of Biology

Master of Science

\begin{abstract}
Hands-on learning is at the heart of science learning. This study examined increased changes of student content knowledge in biology, particularly biotechnology, after a hands-on biotechnology intervention was implemented into a secondary school. A traditional learning school was selected for a control. Both teachers had participated in a biotechnology professional development program called Project Crawfish. Students from both schools took the same assessment before and after their respective units (biotechnology intervention and genetics unit), and the classroom was the unit of analysis $(n=5, n=6$, respectively). The assessment was compared as a whole and then divided into five components, eight questions each: DNA extraction/gel electrophoresis, polymerase chain reaction (PCR), DNA sequencing, bioinformatics, and phylogenetics. The pre-tests were compared to establish a baseline between the two schools. The biotechnology intervention school began with a higher pre-test raw score than the traditional learning school. After adjusting for the pre-test scores, each school was analyzed for increases in student content knowledge and then compared to each other for any significant increases between the two schools. When the entire assessment was analyzed, each school had statistically significant increases in student content knowledge $(<0.0001$ for the biotechnology intervention school and 0.0481 for the traditional learning school). When the schools were compared to each other, a p-value of 0.0543 provided a suggestive relationship that the biotechnology intervention school had a larger increase in student content knowledge. When the assessment was divided into the five components, the traditional learning school had statistically significant increases in student content knowledge in the PCR and DNA sequencing components (0.0459, 0.0043, respectively). The biotechnology intervention school had statistically significant increases in student content knowledge in all five components. However, there were no significant differences in learning between the two schools. Implementing biotechnology through hands-on teaching methods should be considered by secondary science teachers. Further research would scale up this study to include more classrooms.
\end{abstract}

Keywords: hands-on, biotechnology, biology, student content knowledge 


\section{ACKNOWLEDGMENTS}

I would like to thank all my committee members, Dr. Nikki Hanegan, Dr. Byron Adams, and Dr. Joshua Udall, for their time and efforts in helping me accomplish my Masters degree. I would especially like to thank Dr. Hanegan for encouraging me over the years and helping me to become the researcher and teacher I am today. I would also like to thank Dennis Eggett for preparing my statistics. I am very grateful to Patrick Hogle and David Kent for allowing me to use their classrooms for this study. I am most appreciative of my husband Jacob Bigler for being patient and encouraging throughout this time of accomplishing my degree as well as my family for their love and support. 


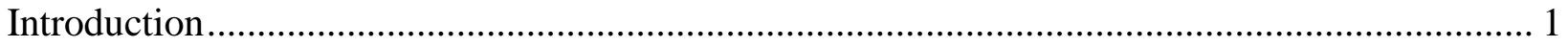

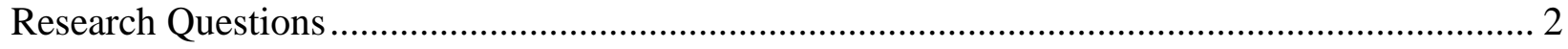

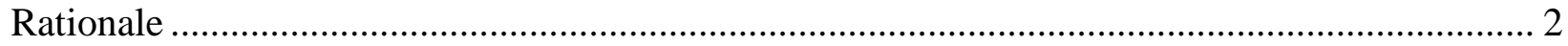

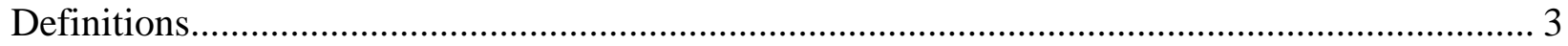

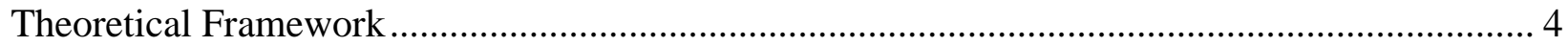

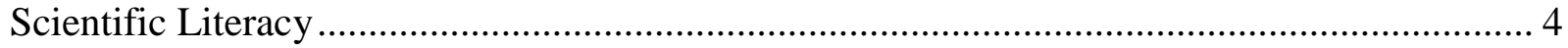

Hands-on Laboratory Experiences......................................................................................... 5

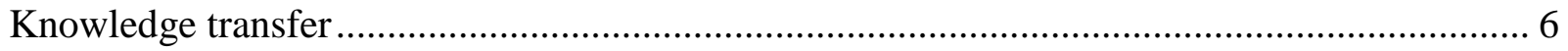

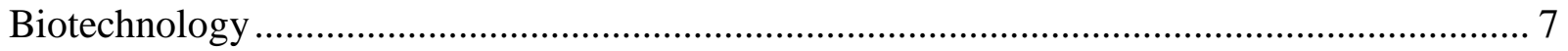

Biotechnology Application to the Science Curriculum .............................................................. 8

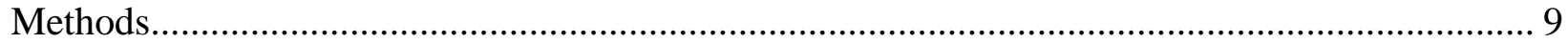

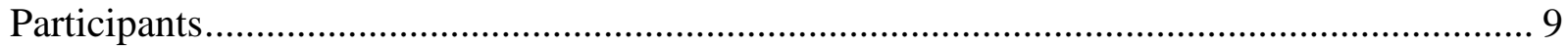

Biotechnology Intervention School Profile ........................................................................... 10

Traditional Learning School Profile ...................................................................................... 11

Assessment Development ............................................................................................... 12

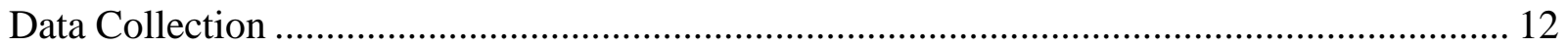

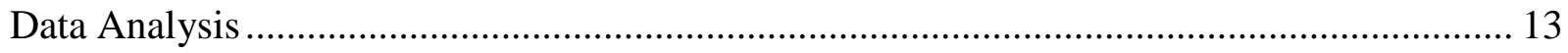

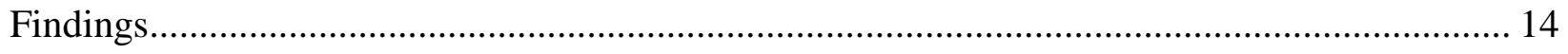

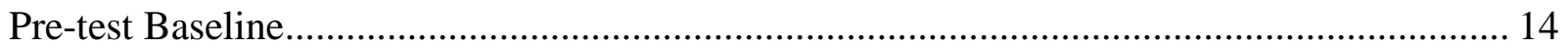

Whole Assessment Comparison ......................................................................................... 14

Five Components of Assessment Comparison ................................................................... 15

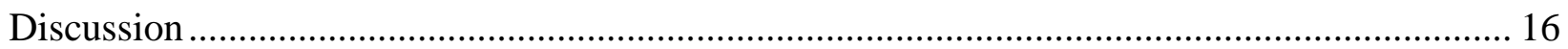

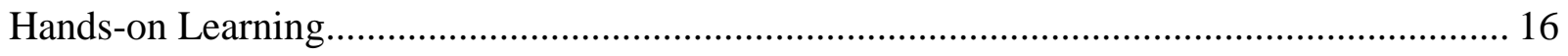

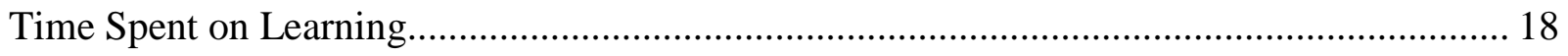

Student Motivation and Confidence ................................................................................... 18

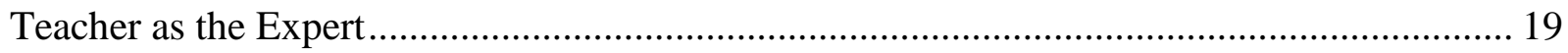

Appropriate Assessment Development.......................................................................... 20

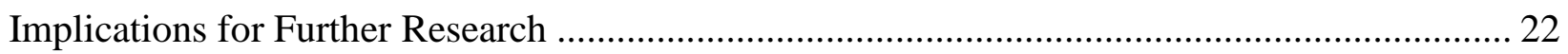

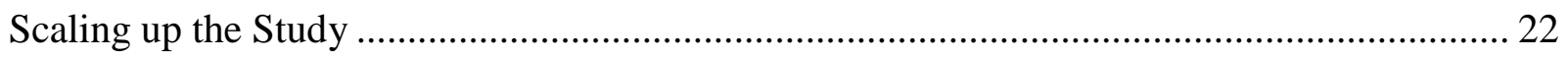

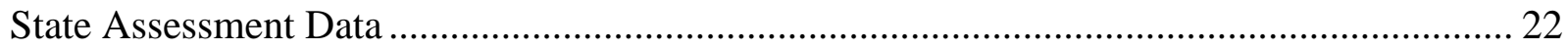

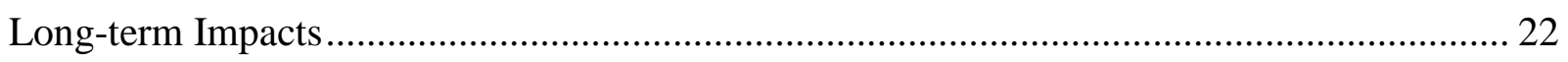

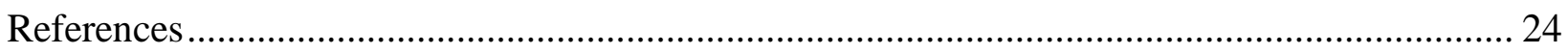

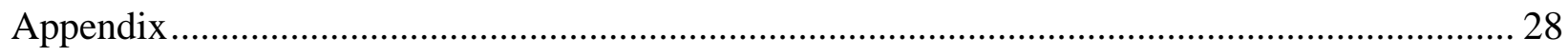




\section{Introduction}

Hands-on learning "is at the heart of science learning” (Nersessian as quoted in Ma \& Nickerson, 2006, p. 2). It allows students to be more engaged in the lesson and actually doing science, promoting science literacy. Hands-on learning can be defined as an "educational experience that actively involves people in manipulating objects to gain knowledge or understanding” (Haury \& Rillero, 1994, p. 11). Hands-on learning is essential for promoting scientific literacy as scientific literacy requires citizens to not only know science content, but also be able to do science.

Biotechnology is a topic of biology which requires hands-on learning in order to fully learn and understand. Biotechnology is applied evolution. It is a process that allows scientists to manipulate whole or parts of organisms' DNA for the specific benefit of humans (Sohan, Waliczek \& Briers, 2002). Biotechnology has advanced biological fields such as genetically modified organisms and stem cell research. Many tools and equipment (i.e. micropipettes, thermal cyclers, gel boxes) are used to study and manipulate DNA.

A recent research study conducted with pre-service teachers showed that biotechnology topics and equipment merited implementation into secondary biology courses (Hanegan \& Bigler, 2009). Upon further investigation it was shown that many in-service teachers were implementing biotechnology topics (96\%), but not equipment (4\%), into their courses (Mansius \& Hanegan, 2008). Reasons teachers gave for not including biotechnology topics and equipment into their courses were: does not fit into the state core curriculum, is too time consuming, and is expensive. Lack of confidence with knowing how to use biotechnology equipment was also an identified factor.

The goal of this study is to determine the increase of content knowledge levels of students participating in a hands-on biotechnology activity as compared to students receiving 
biotechnology information in a traditional learning classroom. A secondary goal is to develop an assessment that measures student learning based on an external intervention. This study uses a pre and post test containing statements about what specific biotechnology equipment and processes are used and why.

\section{Research Questions}

- Does an outside hands-on intervention increase student content knowledge of biotechnology?

- Can a reasonable assessment for an outside educational intervention be developed to measure student learning?

\section{Rationale}

Biotechnology is a relatively new field within scientific research, being around for only about 30 years (Schiller, 2002). It has been in the secondary classroom for even less time, and the educators who are bringing it into the classroom are only utilizing basic techniques and equipment such as gel electrophoresis or manipulating bacteria. Many of these activities are disconnected from what they are used for in scientific laboratories and are merely thought of as “neat” or “cool.” Thus, bringing a biotechnology intervention, which mimics actual laboratory processes and studies, into a secondary classroom, a new setting, has many challenges.

Many educators are not trained to use biotechnology equipment or have not had research experience when they graduate with their teaching certificates (Mansius \& Hanegan, 2008). Thus, professional development courses are desirable to fill the teacher learning gap. However, teachers have to choose to participate in the professional development courses. If biotechnology is something teachers are not interested in or see no use of bringing into their classrooms, they may not participate in biotechnology professional development. Further, if teachers are not trained or do not feel confident teaching biotechnology concepts and using biotechnology 
equipment, their students may not learn biotechnology concepts either (Mansius \& Hanegan, 2008).

Once a teacher has been trained, it needs to be determined if students are learning the concepts as well, specifically through the biotechnology intervention used in this study. The intervention has shown to be effective with teachers, but not yet been shown if the intervention is effective with increasing students’ biotechnology and biology content knowledge. The intervention module is known as Project Crawfish.

Project Crawfish is a collaborative university and secondary school partnership designed to enhance the use of biotechnology in high school settings. This project integrates research-based effective professional development for teachers and classroom activities centered on state biology content standards through inquiry. Students are engaged in research activities including question development, data collection, and analysis. This Project is designed to study the genetic differences among crayfish species and other model organisms, to assemble their relationships among different species of crawfish and those relationships between related phyla. Project Crawfish partners with Tree of Life to help represent these relationships between all species on Earth. By incorporating methods in phylogenetics, bioinformatics, and classroom inquiry students are able to gain a broader perspective and understanding of how life is related at a molecular level. (Hanegan, 2006)

Project Crawfish is a five to six day intervention (depending on the school schedule) where undergraduates teach the lessons alongside the teacher in secondary biology classrooms. There are five components comprising Project Crawfish: DNA extraction and gel electrophoresis, polymerase chain reaction (PCR), DNA sequencing, bioinformatics, and phylogenetics. The intervention described was implemented to measure any increase of student content knowledge as well as to develop an assessment tool.

\section{Definitions}

- Biotechnology is defined as the use of organisms or parts of organisms to create products beneficial to humans 
- Biotechnology topics include cloning, stem cell research, genetically modified organisms, DNA fingerprinting, and forensics, among others

- Biotechnology equipment is limited to micropipettes, centrifuge, vortex, gel boxes and trays, and a thermal cycler

- Intervention is an activity brought in by someone other than the teacher

- A traditional learning classroom is where lectures and worksheets are primarily used to teach content standards

\section{Theoretical Framework}

\section{Scientific Literacy}

One of the goals addressed by the National Science Education Standards (NSES) was to

create a more science literate society (NRC, 1996). They defined science literacy as:

Scientific literacy means that a person can ask, find, or determine answers to questions derived from curiosity about everyday experiences. It means that a person has the ability to describe, explain, and predict natural phenomena. Scientific literacy entails being able to read with understanding articles about science in the popular press and to engage in social conversation about the validity of the conclusions. Scientific literacy implies that a person can identify scientific issues underlying national and local decisions and express positions that are scientifically and technologically informed. A literate citizen should be able to evaluate the quality of scientific information on the basis of its source and the methods used to generate it. Scientific literacy also implies the capacity to pose and evaluate arguments based on evidence and to apply conclusions from such arguments appropriately. (NRC, 2006, p. 22)

Being science literate does not mean that a person can recall memorized facts. It is a skill requiring action that needs to be learned and developed. Hands-on laboratory activities allow students to experience science and develop the skill of being science literate (Haury \& Rillero, 1994). 
Hands-on Laboratory Experiences

Hands-on science allows for "science learning to better resemble science practice" (Edelson, 1997, p.1) because it is an "educational experience that actively involves people in manipulating objects to gain knowledge or understanding” (Haury \& Rillero, 1994, p. 11). The key word is 'actively'. Learning is not a passive activity. When students are involved in handson science, they are engaged in their science learning, and thus promoting scientific literacy. The NSES "call for students to be actively engaged in solving problems that allow them to realize applications beyond the scope of the classroom” (NRC, 1996).

There are many benefits to implementing hands-on activities within the science classroom. Hands-on activities are a way for teachers to engage students in knowledge transfer with students’ past experiences as well as promoting further knowledge transfer by providing new experiences. "Good teachers know that students become more engaged in learning when they are participating in a 'hands-on' activity, and that this engagement promotes deeper knowledge acquisition” (Dunham, Wells \& White, 2002, p. 8). When students are able to see what they are learning about and really interact with the subject material, the material becomes less abstract and students will begin to ask more open-ended questions allowing for deeper understanding. Hands-on activities allow students to make connections between the various science topics that are generally taught in a disjointed manner (Kirkpatrick, Orvis \& Pettendrigh, 2002).

Doing hands-on activities gives students ownership for their learning (Dunham et al., 2002). Students are more likely to remember the material better and the retention level is improved (Haury \& Rillero, 1994). Students’ critical thinking and discovery skills are developed in interactive settings because students have to rely on the evidence gathered for interpretation rather than looking to an all-knowing authority, be able to interpret the data, and form 
conclusions. Hands-on laboratory experiences have also shown to increase student motivation (Haury \& Rillero, 1994; Paris, Yambor \& Packard, 1998).

Ma and Nickerson (2006) came up with four educational goals for laboratory learning, whether it's a hands-on or simulated activity: conceptual understanding, design skills, social skills, and professional skills. They found that hands-on activities fulfill all four of these educational goals. Students were able to understand the concepts being taught by the activity, design skills were further developed if students were given the opportunity to design their own lab, hands-on activities require communication with the teacher and peers, and students were better prepared with the skills required for a given profession.

\section{Knowledge transfer}

Knowledge does not just consist of facts, but “concepts plus their relations to other concepts” (Faletti, 1985, p. 2). Transfer is “the cognitive mechanisms concerned with students' use of what they have learned to solve new problems” (Schonborn \& Bogeholz, 2009, p. 933). There are two directions of knowledge transfer during a student's K-12 education: horizontal and vertical transfer. Horizontal transfer refers to connecting knowledge between disciplines (e.g. how biology relates with chemistry and physics). Vertical transfer refers to connecting knowledge among the different levels within a discipline (e.g. connecting a cell to a tissue). Both types of transfer are important for learning in order to make connections and problem solve.

In order for effective knowledge transfer to occur within a classroom, learning has to occur within the proper context. Teachers need to provide the context where the new understanding will be useful. That way, students will be more able to recognize situations where they can apply their new knowledge. Otherwise, the concept learned merely becomes a memorized fact or a fun experience with no relevance to anything else (Edelson, 1997). 


\section{Biotechnology}

Biotechnology is discussed in the media, demonstrated in movies and television shows and more states are requesting the general public to vote on biotechnical issues. For example, the television show, CSI, uses DNA fingerprinting, one aspect of biotechnology, to match suspects to the crime scene. State propositions including funding for stem cell research and personhood at conception (limiting in vitro fertilization) were placed on ballots November 2008 in several states including Colorado. Biotechnology is also believed to have a profound impact on the economy (Kirkpatrick et al., 2002; Simpkins, Davis-Kean, \& Eccles, 2006). The technologies brought forth through the advancement of science and biotechnology will "alter the way we fight diseases, grow crops, and feed our population” (Kirkpatrick et al., 2002, p. 31).

Biotechnology is one of the fastest growing areas in biology both by scientific and community interest (Moreland, Jones \& Cowie, 2006) and is used to advance many areas such as cloning, stem cell research, genetic engineering, and phylogenetic research. As many of these topics are included in political debate, the general public needs more education about these processes to make informed citizenship decisions (Braun, 2002; Braun \& Moses, 2004; Colavito, 1999; Dawson, 2007; Dawson \& Schibeci, 2003; Glynn, Taasoobshirazi, \& Brickman, 2007; Harms, 2002; Munn et al., 1999; Sohan, Waliczek \& Briers, 2002). According to Schiller (2002), surveys have indicated that when consumers are properly informed of desirable characteristics relating to genetically modified foods or other applied uses of biotechnology, consumers are more likely to have positive attitudes. The classroom is an ideal setting for students to debate the issues and decide what is best for themselves and future generations through hands-on experiences (Leslie \& Schibeci, 2006).

Biotechnology is applied evolution providing many benefits for both teachers and students when implemented in a biology course. Teachers are able to enhance students’ problem 
solving skills by providing a hands-on biotechnology activity. Students develop better problem solving skills, are able to think more critically (Hurd, 2001), and learn to become collaborators with their peers wile engaging student interest (Moreland et al., 2006). They learn that science is not an individual task, but scientists work together in order to find solutions (Hurd, 2001).

\section{Biotechnology Application to the Science Curriculum}

Life Sciences, Content Standard E from the National Science Education Standards (NSES) for grades 9 - 12 contains a section titled "Understandings about Science and Technology”. This section states: "Science often advances with the introduction of new technologies...New technologies often extend the current levels of scientific understanding and introduce new areas of research” (NRC, 1996). The NSES indicate the importance of technology being used in the classroom, and the importance for students to understand the relationship between science and technology.

The NSES also has a standard for biological evolution. It states "the millions of different species of plants, animals, and microorganisms that live on earth today are related by descent from common ancestors” (NRC, 1996). This study addresses this NSES standard by one of the goals of the hands-on biotechnology intervention being to show how closely related four model organisms (Arabidopsis, frog, worm, and crawfish) are. The intervention also allows students to do exactly what scientists do in the laboratory when sequencing a particular organism's genome.

In the Utah Biology Core Curriculum, biotechnology relates to standards IV and V. Standard IV states: "Students will understand that genetic information coded in DNA is passed from parents to offspring by sexual and asexual reproduction” (USOE, 2003). The basic structure of DNA is the same in all living things. Changes in DNA may alter genetic expression. Under this standard, objective 3.f states: Research, report, and debate genetic technologies that may improve the quality of life (USOE, 2003). This would relate more to bringing biotechnology 
topics into the classroom. By actually using biotechnology equipment, the students will be able to apply their knowledge about the structure and properties of DNA to explain the phenomena in each step of each process.

Standard V states: "Students will understand that biological diversity is a result of evolutionary processes” (USOE, 2003). This whole standard can be related to biotechnology because the biotechnology equipment used in the project and evolution are the product of manipulating one molecule: DNA. Biotechnology can be applied by using bioinformatics and phylogenetics software to create phylogenetic trees. Students can estimate how closely related two organisms are, and they can discuss the mechanisms that drove organisms into becoming separate species.

\section{Methods}

This study was a mixed-methods study. The assessment comprises the quantitative data, and the teacher and student interviews make up the qualitative portion of the study and were used to support results obtained from the assessment. Data were collected from secondary biology classrooms from two schools. Data consisted of the following: 1) pre and post tests; 2) either the biotechnology intervention or traditional learning of biotechnology; and 3) student and teacher interviews from the biotechnology intervention school. Although the teacher at the intervention school was not assessed, the teacher has a better idea of student learning taking place within the classroom than what would be shown by the pen and paper assessment. The interview was used to further support the assessment as well as the student interviews.

\section{Participants}

The participants in this study were students registered in biology classes at two public alternative high schools. There were no significant profile differences between the two population groups. The biotechnology intervention school consisted of five biology classes 
totaling about 125 students. The traditional learning school consisted of six biology classes totaling 93 students. Student participation in the study was voluntary; however, all students were able to participate in the biotechnology intervention or traditional learning classroom activities. Biotechnology Intervention School Profile

The biotechnology intervention teacher had participated in the Project Crawfish professional development program encouraging implementation of biotechnology equipment and thus had some background knowledge of the equipment and how to implement it in the classroom. Before the intervention was implemented, the teacher used seven days to provide background information. The biotechnology intervention was conducted over a six-day period. The intervention consisted of protocols pertaining to DNA extraction and gel electrophoresis, Polymerase Chain Reaction (PCR), DNA sequencing, bioinformatics, and phylogenetics. All chemicals were determined safe to use in a secondary classroom setting.

The students were divided into groups of 3-4, and each group extracted DNA from one of four model organisms (Arabidopsis, frog, worm, and crawfish). All four organisms were used within one class period. The students obtained a tissue sample from the organism, which sat overnight allowing for maximum cell lysage. Using Qiagen’s DNA extraction kits for plant and animal tissues, the students went through a series of washings and centrifuging with different buffers until the only molecule left was the organism’s DNA.

In order to check that the DNA extraction was successful, gel electrophoresis was performed. Each group loaded a sample of their organism’s DNA onto an agarose gel. The gel was already prepared for the students (to save class time) and contained SYBR Safe DNA stain, which stains DNA as electrophoresis occurs. Using a portable light box containing a UV bulb, students were able to see if their extraction was successful as soon as the gel was finished running. 
If the extraction was successful, the next step was to amplify the 18S rRNA gene using a thermal cycler. A discussion of what is occurring during PCR was necessary for students to understand why they added the extra solutions (Master Mix and primers) to their DNA. The discussion also allowed students to connect their knowledge DNA replication processes occurs to what was occurring in the thermal cycler. If extraction was not successful, back up samples were prepared by the researchers so students could continue with the biotechnology intervention.

The PCR samples were taken back to the university for DNA sequencing. Since students are not involved with this step, but will later analyze the sequences during the bioinformatics step, a discussion was also necessary here in order for students to understand what the sequences were and where they came from. During bioinformatic computer exercieses, students used BioEdit, ClustalX, and Mega 4 freeware programs available for download online to create a consensus sequence, which were matched to a specific species on GenBank.

All of the groups were able to compile their consensus sequences and create a phylogenetic tree comparing all model organisms. Since the groups all amplified the 18S rRNA gene, the phylogenetic tree was based on that one gene. Students also made the connection that all organisms are related to a common ancestor, which is found in the education standards. Phylogenetics was also taught through two other activities where students compiled their own tree instead of the computer making the tree for them. These activities helped the students be able to read and interpret the phylogenetic tree of the model organisms.

\section{Traditional Learning School Profile}

The traditional learning teacher had also participated in the Project Crawfish professional development program, but chose not to use the professional development equipment or protocols. Thus, the teacher had nearly the same background of biotechnology equipment and was selected as a control for this study. The whole unit lasted about one month. The teacher 
taught biotechnology concepts through lectures and small activities centered around genetics topics. The topics included in this unit were DNA structure, replication, mutation and a few genetic technologies such as cloning and gene therapy.

A typical activity focused on a specific concept to enhance learning (such as how to translate DNA to mRNA and transcribe mRNA to protein). The activities did not mimic scientific processes. There were minimal hands-on learning opportunities for the students. The only lab the students were able to participate in was a gel electrophoresis lab, to demonstrate properties of DNA. The gel electrophoresis lab was not connected to other biotechnology processes such as PCR or applied evolution technologies.

\section{Assessment Development}

Assessing hands-on laboratory experiences can be very difficult and much controversy exists around the best method. Some possible methods include a pen and paper quiz or test, oral examination, or a performance assessment. Each of these methods has pros and cons and place within the classroom. Effective assessment may also depend on each individual student and desirable learning outcomes by the teacher.

For the purposes of this study, the researchers developed an assessment that can be used in a variety of classrooms and effectively assess large numbers of students. Thus, the pen and paper method was chosen. The assessment includes questions not only pertaining to knowledge acquisition of the particular biotechnology processes and equipment uses, but also what the purpose is for each step of the biotechnology hands-on intervention (Hanegan \& Bigler, 2009).

\section{Data Collection}

This study assessed student knowledge of specific biotechnology processes as well as biotechnology purposes. A pre-test was given before the biotechnology intervention and genetics unit and compared to an identical post-test given after the intervention and unit (see Appendix). 
The pre- and post-tests represent the content knowledge of the students. The 40 statements were evaluated using a Likert scale ranging from 1 (false) to 5 (true). There were follow-up student and teacher interviews from the intervention school to further investigate student learning (see Appendix).

\section{Data Analysis}

First, the pre-test scores were compared between the intervention and traditional learning schools in order to establish group’s content knowledge level before the units. Second, the preand post- tests were statistically analyzed using an ANOVA test and the classroom was the unit of analysis ( $\mathrm{n}=5$ for the intervention school, $\mathrm{n}=6$ for the traditional learning school) for an increased change in content knowledge by the students from each of the two groups. The pre-test was used as a covariate in the analysis. The assessment was looked at as a whole, and then broken down into five components: DNA extraction/gel electrophoresis, PCR, DNA sequencing, bioinformatics, and phylogenetics. Third, the test scores were compared between each group using an ANOVA test after adjusting for the pre-test scores to determine if there was a significant increase in student content knowledge from one group compared to the other. This indicated if the intervention was effective for student learning. The student and teacher interviews of the intervention school were transcribed, analyzed, and used to triangulate, or expand, the quantitative data.

The pre- and post-test assessments were matched by individual students. There were many students present for the pre-test and not the post-test and vice versa. Students who only took either the pre or post test were excluded from the final analysis. Fifty-six students' assessments from five classrooms were analyzed from the intervention school, and 47 assessments from six classrooms from the traditional learning school. 


\section{Findings}

\section{Pre-test Baseline}

The pre-tests from both schools were compared to establish a baseline of students’ content knowledge. This allowed for an accurate analysis of student learning between the two groups because the two schools' knowledge levels did not start at the same point. Comparison of each groups' pre-test scores showed that the traditional learning classroom scored lower on the pre-assessment than the intervention classroom (see Table 1).

Table 1 Pre-test Assessments

\begin{tabular}{|c|c|c|}
\hline School Type & Traditional Learning & Biotechnology Intervention \\
\hline Pre-test Estimate & 125.49 & 134.32 \\
\hline
\end{tabular}

The table records the pre-test score estimates of each classroom type. There are 200 possible points on the assessment (40 questions; 5 points each).

\section{Whole Assessment Comparison}

The assessments were analyzed as a whole, all 40 questions were included (see Table 2). First, the traditional learning classrooms $(n=6)$ were analyzed to see if there was any increases in student content knowledge from the pre- to the post-test. There was a statistically significant increase of student content knowledge $(\mathrm{p}=0.0481)$. Second, the intervention classrooms $(n=5)$ were analyzed, and there was a statistically significant increase of student content knowledge (p $<0.0001)$. The two classrooms were compared by adjusting for the pre-test and comparing the increases of learning from the pre-test to the post-test. A p-value of 0.0543 provides a suggestive relationship that the biotechnology intervention school gained more knowledge than the traditional learning school. 
Table 2 Whole Assessment Increase of Student Content Knowledge

\begin{tabular}{|c|c|c|c|}
\hline School Type & $\begin{array}{c}\text { Traditional Learning } \\
(\mathbf{n = 6 )}\end{array}$ & $\begin{array}{c}\text { Biotechnology } \\
\text { Intervention } \\
(\mathbf{n}=5)\end{array}$ & Comparison of Schools \\
\hline $\begin{array}{c}\text { Content Knowledge } \\
\text { Increases p-values }\end{array}$ & 0.0481 & $<0.0001$ & 0.0543 \\
\hline
\end{tabular}

The table records the p-values of comparing the pre- and post-tests from each classroom and then comparing both schools.

\section{Five Components of Assessment Comparison}

The assessment was divided into five components, eight questions each: DNA extraction/gel electrophoresis, PCR, DNA sequencing, bioinformatics, and phylogenetics. The purpose was to determine if students’ increased content knowledge in any single area. Each classrooms' pre- and post-tests were compared for statistically significant increases of student content knowledge. The traditional learning classrooms had significant increases of knowledge for the PCR and DNA sequencing components of the assessment $(p=0.0459, p=0.0043$, respectively). The intervention classrooms had significant increases of content knowledge in all five components (see Table 3). Further, the two schools were compared to each other in the same manner that the whole assessment was compared. There were no categories that indicated a statistically significant difference in learning between the traditional learning and intervention schools. All results of the analysis are recorded in Table 3.

Table 3 Analysis Results of the Assessment's Five Components

\begin{tabular}{|l|l|l|l|}
\hline $\begin{array}{l}\text { Assessment } \\
\text { Component }\end{array}$ & $\begin{array}{l}\text { Traditional Learning } \\
\mathbf{( n = 6 )}\end{array}$ & $\begin{array}{l}\text { Biotechnology } \\
\text { Intervention (n=5) }\end{array}$ & Comparison \\
\hline $\begin{array}{l}\text { DNA extraction/gel } \\
\text { electrophoresis }\end{array}$ & 0.1486 & 0.0027 & 0.3141 \\
\hline PCR & 0.0459 & 0.0001 & 0.2092 \\
\hline DNA Sequencing & 0.0043 & 0.0007 & 0.8504 \\
\hline Bioinformatics & 0.5232 & 0.0004 & 0.0636 \\
\hline Phylogenetics & 0.7793 & 0.0128 & 0.1334 \\
\hline
\end{tabular}

The table records the $\mathrm{p}$ values found when the assessment was divided into the five components corresponding with the intervention. Each classroom's pre- and post-tests were compared for significant increases of student content knowledge. The two classrooms were compared to each other. 


\section{Discussion}

From comparing the pre-test raw scores between the biotechnology intervention and traditional learning schools (134.32, 125.49, respectively) one could say that the traditional learning school had more room to improve. When the whole assessment was statistically analyzed, a suggestive relationship was shown that the biotechnology intervention school improved more than the traditional learning school $(p=0.0543)$. This was most likely due to the fact that the biotechnology intervention provided hands-on learning and opportunities for knowledge transfer from students’ baseline knowledge.

\section{Hands-on Learning}

Hands-on learning within education has been said to be essential to "make science come alive” for students (Haury \& Rillero, 1994). One student in this study stated learning science through hands-on experiences and laboratories is similar to learning how to play a musical instrument:

Student ${ }^{1}$ : You can't learn how to play an instrument by reading out of a book, you have to actually go do it before you learn.

This statement was backed up by several other students commenting on learning through handson laboratories:

Student $^{2}$ : Actually doing it, instead of watching how to do it.

Student ${ }^{3}$ : I learn way more if I do things myself.

Student ${ }^{4}$ : When we're actually doing, it's like "Oh, so this is what that means."

Student $^{5}$ : Yeah, it's kind of hard to imagine all this stuff.

One student wanted to do the biotechnology intervention again with less guidance from the teacher and undergraduate students that helped with the intervention in order to deepen their knowledge about DNA and the equipment used in the intervention: 
Student ${ }^{6}$ : If we kept doing hands-on stuff, doing things like learning the tools, and then working on the DNA again, you know, in groups and not have you guys there, and let the kids sit there and figure it out, I bet that would help a lot.

Molecular biology in itself is an abstract topic for most high school biology students. DNA, RNA and protein cannot be physically handled or seen by the naked eye. Biotechnology topics such as cloning are also seen as very abstract concepts. One cannot see DNA being replicated within bacteria or a thermal cycler. However, when students were able to physically add all of the required ingredients needed for DNA amplification to occur with an explanation of why all of those things were added, PCR became more meaningful and less abstract:

Student $^{7}$ : [I learned] how we could clone DNA. It was really interesting that we could do that. How we split up the DNA and it rebuilds itself with the enzymes.

The assessment component PCR had the largest increase in learning of all the intervention components $(\mathrm{p}=0.0001)$. The student interviews made it more clear why. When asked what they learned through the biotechnology intervention, most students interviewed remembered they could copy DNA. Actually doing the steps required for PCR to occur instead of reading about it or watching someone else do the steps actually made science come alive for these students.

However, both interviews and statistical data indicated that DNA sequencing is still the "black box" of biotechnology. One aspect of the biotechnology intervention students never get to actually do and experience hands-on is the actual viewing or coding the DNA from the PCR sample. Currently, as more expensive equipment and computer programs are required for this necessary step, DNA sequencing is not feasible for hands-on learning in secondary classrooms. Thus, students are not fully engaged with this process, but rather learn about it through discussion, making learning minimal. From the findings in this study, it was shown that both the biotechnology intervention and traditional learning schools had significant increases of knowledge $(p=0.0007, p=0.0043$, respectively), but those increases were not significant from 
each other $(p=0.8504)$. Although DNA sequencing was a newer concept for students, they could not be fully engaged with that concept. Thus, DNA sequencing is considered the "black box" for students in this study.

\section{Time Spent on Learning}

A previous study reported that one of the main reasons science teachers do not incorporate biotechnology equipment into the classroom is because biotechnology equipment takes too much classroom time (Mansius \& Hanegan, 2008). Many teachers already feel pressed to get through the whole state curriculum and prepare their students for state science assessments. In this study, the traditional learning school spent more time on their genetics unit (one month, about 20 school days) than the biotechnology intervention school (13 days total preparation and the intervention). As a suggestive relationship was shown that the biotechnology intervention school had a larger increase of student content knowledge than the traditional learning school $(\mathrm{p}=0.0543)$, it is suggested that less time is needed to teach genetics concepts by implementing biotechnology equipment. This finding is contrary to what most teachers perceive about implementing biotechnology equipment into their classrooms.

\section{Student Motivation and Confidence}

Hands-on learning has also been shown to increase student motivation and confidence (Haury \& Rillero, 1994; Paris, Yambor \& Packard, 1998). Although looking at increases in motivation and confidence were not primary goals of this study, nor statistically looked at, the student and teacher interviews revealed a possible increase in student motivation and confidence:

Student $^{8}$ : It was fun, cause we're in high school, and we got to do that. Not most high schools can do that.

Teacher ${ }^{1}$ : A lot of times these students, they'll act disinterested when really they are...Judging by how many comments after we did the DNA extraction and PCR, the students really, really liked it. They recognize the opportunity they had. Even if their 
motivation, or their overall academic drive is pretty low, I think generally that they responded really well to it.

To them [the students], I believe it still has value because if nothing more than getting the tools of biotechnology in their hands, and having them go through those things, I think it builds confidence.

When they leave school, and they see DNA on the news, they will at least have that fundamental thing that will be burned into their memory forever.

There was also evidence from the student interviews that those who were interested in the intervention learned more. Below are responses to the question "Do you think most of the students understood the activity?”

Student $^{9}$ : The ones that got involved in it - who want to learn about it.

Student ${ }^{10}$ : The ones that got into it - that got interested.

\section{Teacher as the Expert}

Within a secondary biology course, the teacher is considered the life sciences expert by the students. An expert is considered to have good reasoning skills and better able to make connections within the discipline better than novices, i.e. the students (Gess-Nesome \& Lederman, 1991). However, when an unknowledgable teacher resumes the role of expert, attempts to transfer knowledge to the students or novices becomes disconnected (Faletti, 1985). Further, if a teacher is unknowledgeable or lacks confidence with biotechnology, the topic may be overlooked in the curriculum and not taught to students. Mangione-Leslie, Dockers, and Wavering (2005) showed a positive correlation between confidence and knowledge with preservice teachers; if a teacher was not confident, teacher knowledge decreased.

What makes an expert an expert is not only what a person knows, but how that person is able to "organize their knowledge [as well as] use the knowledge to solve problems and understand the world around them” (Kozma \& Russell, 1997, p. 950) even when a certain phenomenon is not easily noticed through everyday experiences. Novices, on the other hand, depend upon a disconnected string of facts which they can relate to everyday experiences 
providing a knowledge base for further knowledge attainment and later connections to be made (Kozma \& Russell, 1997). The teacher's role as expert in a biology course is to provide opportunities for student further knowledge gain and knowledge transfer.

Aside from what students bring to the classroom, teachers are the most influential factor on student learning (Hattie, 2003). It is the biology teacher's responsibility to keep up with new scientific discoveries and educate students in order to promote scientific literacy (Schonborn \& Bogeholz, 2009). It has been shown that teachers with better developed teaching strategies and higher knowledge acquisition are better able to transfer knowledge to their students (GessNewsome \& Lederman, 1991). Not only do teachers need to transfer knowledge to students, but also the skills required for connecting new knowledge with the student's previous experiences as well as knowledge previously attained (Schonborn \& Bogeholz, 2009). A problem arises when a teacher cannot teach all that he/she knows (Ray, 2009).

Both teachers in this study had nearly the same backgrounds with biotechnology topics and equipment because they participated in the same professional development program. However, the data suggests that the traditional learning teacher was not as successful with transferring knowledge as the biotechnology intervention teacher. One possible reason for this difference is the implementation of teaching methods: hands-on versus traditional learning. Providing students with hands-on learning and authentic science opportunities may have a bigger impact on student learning and increasing student content knowledge than traditional teaching methods such as lecturing and disconnected activities.

\section{Appropriate Assessment Development}

One factor behind using alternative high schools in this study was that generally at-risk students are also the least motivated students. Since this assessment was successfully applied to this alternative population, then it could possibly be generalized to a larger traditional population 
of students. A limitation for using a pen and paper test is the test becomes more of a vocabulary test than actually assessing student learning. This was brought out in both the student and teacher interviews. When the students were asked specifically what new vocabulary they learned, many were able to describe a process or piece of equipment, but they had a hard time remember the actual words and names:

Student $^{11}$ : The gel uh.....I can’t remember what it was called.

Student $^{12}$ : What those machines did, like the things that spun it around.

Other times, students would remember the words but could not remember how they were connected to the intervention.

Student ${ }^{13}$ : I did learn a new word - gene splicing. I have no clue what it means though. For this population of students, vocabulary is a struggle and a verbal assessment may have been more appropriate.

The biotechnology intervention teacher also brought this up in the interview:

Teacher ${ }^{1}$ : I think vocabulary is always a problem here. A lot of these students don't they can't break down words. They have low reading levels so they - when they come to a word they don't know, they don't try to figure out what it means. What they do is they'll just skip it or just guess. And like where it says 'centrifugation', a lot of them lack the skills to recognize the word centrifuge. Even if they know what a centrifuge is, they can't put those together.

I wish we had a better way to assess who learned what than the little test because what you're faced with is I can give a student within this school, give him a written pen-andpaper test, and he will take it, fail it miserably, and then I can pull them in the office and ask them questions, and their reading level prohibits them from actually answering the question accurately. So a test doesn't - never really assesses what a student learns well, but here especially, it's a difficult way to assess learning.

For a more accurate approach to assess student learning, various assessments should be used instead of a one-size-fits-all method.

The students interviewed felt that the assessment was more understandable after the biotechnology intervention than before. This was represented by comments such as "I recognized 
more words" or "it was definitely easier afterwards" in response to the question "Did you find that you understood the test?” Students also felt they would learn the vocabulary better and pick up on more details if given the opportunity to do the biotechnology intervention again.

$$
\text { Implications for Further Research }
$$

\section{Scaling up the Study}

Only two schools and a total of 11 classrooms were used in this study. Overall, there were no statistically significant differences in increases of knowledge between the biotechnology intervention and traditional learning schools possibly because of the small n sizes. However, the suggestive relationship that the biotechnology intervention does have an impact on student learning is promising. It provides reason to scale this study up to include more classrooms and various population groups in order to determine the effectiveness of the biotechnology intervention.

\section{State Assessment Data}

The only assessment used to determine the effectiveness of the biotechnology intervention was the assessment developed by the researchers specifically addressing the intervention. Since biotechnology does relate to the National Science Education Standards and thus state education standards, the next step would be to examine state science assessment scores for this testing domain. The scores of the classrooms which participated in the biotechnology intervention could be compared to classrooms that did not incorporate the intervention and help determine if the intervention has an impact on a standardized science assessment.

\section{Long-term Impacts}

One goal of the biotechnology intervention is to not only provide an opportunity for students to do what scientists are doing in laboratories world-wide, but also to increase student interest in science and enter into a science career. The study conducted merely looked at short- 
term impacts the biotechnology intervention had; such as: increasing student content knowledge and possibly increasing student confidence in the secondary classroom. Future studies could track these students after high school and record how many of the students entered into higher education, and of those, how many chose a science degree. 


\section{References}

Braun, R. (2002). People’s concerns about biotechnology: some problems and some solutions. Journal of Biotechnology, 98, 3-8.

Braun, R. \& Moses, V. (2004). A public policy on biotechnology education: What might be relevant and effective? Current Opinion in Biotechnology, 15, 246-249.

Colavito, M. C. (2000). Integrating biotechnology into a non-majors biology curriculum. Journal of Industrial Microbiology \& Biotechnology, 24, 308-309.

Dawson, V. (2007). An exploration of high school (12 - 17 year old) students' understandings of, and attitudes towards biotechnology processes. Research Science Education, 37, 5973.

Dawson, V. \& Schibeci, R. (2003). Western Australian high school students’ attitudes towards biotechnology processes. Journal of Biological Education, 38(1), 7-12.

Dunham, T., Wells, J., \& White, K. (2002). Photobioreactor: Biotechnology for the technology education classroom. The Technology Teacher, 62(2), 7-12.

Edelson, D. C. (1997). Realising authentic science learning through the adaptation of scientific practice. International Handbook of Science Education (eds. K. Tobin \& B. Fraser). Kluwer, Dordrecht, NL.

Faletti, J. (1985). Systematic representation of biology knowledge. Presented at National Association for Research in Science Teaching 1986 annual meeting: San Fransisco, California.

Gess-Newsome, JJ. \& Lederman, N. G. (1991). Biology teachers’ perceptions of subject matter structure and its relationship to classroom practice. Presented at National Association for Research in Science Teaching 1992 annual meeting: Boston, Massachusetts. 
Glynn, S. M., Taasoobshirazi, G., Brickman, P. (2007). Nonscience majors learning science: A theoretical model of motivation. Journal of Research in Science Teaching, 44(8), 10881107.

Hanegan, N. L. (2006). Project Crawfish: A biotechnology short-course manual. Retrieved from http://crayfish.byu.edu/projectcrawfish/

Hanegan, N. L. \& Bigler, A. (2009). Infusing authentic inquiry into biotechnology. Journal of Science Education and Technology, 109(2), 110-134.

Harms, U. (2002). Biotechnology education in schools. Electronic Journal of Biotechnology, 5(3), 205-211.

Haury, D. L. \& Rillero, P. (1994). Perspectives of hands-on science teaching. ERIC Clearing House for Science, Mathematics, and Environmental Education. Columbus, $\mathrm{OH}$.

Hattie, J. (2003). Teachers make a difference: What is the research evidence? Keynote presentation at the Building Teacher Quality: The ACER Annual Conference, Melbourne, Australia.

Hurd, P. D. (2001). The changing image of biology. The American Biology Teacher, 63(4), 233235.

Kirkpatrick, G., Orvis, K., \& Pittendrigh, B. (2002). A teaching model for biotechnology and genomics education. Journal of Biological Education, 37(1), 31-35.

Kozma, R. B. \& Russell, J. (1997). Multimedia and understanding: Expert and novice responses to different representations of chemical phenomena. Journal of Research in Science Teaching, 34(9), 949-968.

Leslie, G. \& Schibeci, R. (2006). Teaching about designer babies \& genetically modified foods: Encouraging the teaching of biotechnology in secondary schools. The American Biology Teacher, Online Publication, 98-103. 
Ma, J. \& Nickerson, J. V. (2006). Hands-on, simulated, and remote laboratories: A comparative literature review. ACM Computing Surveys, 38(3), article 7.

Mangione-Leslie, Dockers, and Wavering, (2005). What do they know? A look into preservice teachers’ earth science content knowledge. Presented at The Association for Science Teacher Education Annual Conference: Colorado Springs, Colorado.

Mansius, A. L. \& Hanegan, N. L. (2008). Factors concerning integration of biotechnology into secondary biology. Presented at American Education Research Association 2008 Annual Meeting: New York, New York.

Moreland, J., Jones, A., \& Cowie, B. (2006). Developing pedagogical content knowledge for the new sciences: The example of biotechnology. Teaching Education, 17(2), 143-155.

Munn, M., Skinner, P. O., Conn, L., Horsma, H. G., \& Gregory, P. (1999). The involvement of genome researchers in high school science education. Genome Research, 9(7), 597-607.

National Research Council. (1996). National science education standards. Washington DC: National Academy Press.

Paris, S. G., Yambor, K. M., \& Wai-Ling Packard, B. (1998). Hands-on biology: A museumschool-university partnership for enhancing students’ interest and learning in science. The Elementary School Science, 98(3), 267-288.

Ray, T. (2009). Rethinking Polanyi’s concept of tacit knowledge: From personal knowing to imagined institutions. Minerva, 47, 75-92.

Schiller, T. (2002). From laboratory to market: The biotechnology industry in the Third District. Business Review: Federal Reserve Bank of Philadelphia, Fourth Quarter, 6-16.

Schonborn, K. J. \& Bogeholz, S. (2009). Knowledge transfer in biology and translation across external representations: Experts’ views and challenges for learning. International Journal of Science and Mathematics Education, 7, 931-955. 
Simpkins, S. D., Davis-Kean, P. E., \& Eccles, J. S. (2006). Math and science motivation: A longitudinal examination of the links between choices and beliefs. Developmental Psychology, 42(1), 72-83.

Sohan, D. E., Waliczek, T. M., \& Briers, G. E. (2002). Knowledge, attitudes, and perceptions regarding biotechnology among college students. Journal of Natural Resources and Life Sciences Education, 31, 5-11.

Utah State Office of Education, (USOE). (2003). Utah Science Core Curriculum [Online]. Available: www.usoe.k12.ut.us/curr/science/core/bio/docs/BIOCORE03.doc 


\section{Pre- and Post-test for students}

Introduction: Read each statement carefully and decide how true you think each statement is. Circle a number: 1 - completely false; 2 - somewhat false; 3 - neither false or true; 4 somewhat true; or 5 - completely true.

\begin{tabular}{|c|c|c|c|c|c|}
\hline & $\begin{array}{l}\text { Completely } \\
\text { False }\end{array}$ & & $\begin{array}{c}\text { Neither } \\
\text { False Nor } \\
\text { True }\end{array}$ & & $\begin{array}{l}\text { Completely } \\
\text { True }\end{array}$ \\
\hline 1. Every cell in a tissue sample has DNA. & 1 & 2 & 3 & 4 & 5 \\
\hline $\begin{array}{l}\text { 2. Centrifugation causes heavier } \\
\text { substances to go to the bottom of a test } \\
\text { tube }\end{array}$ & 1 & 2 & 3 & 4 & 5 \\
\hline $\begin{array}{l}\text { 3. Gel electrophoresis uses an electric } \\
\text { current to pull DNA across a gel }\end{array}$ & 1 & 2 & 3 & 4 & 5 \\
\hline 4. DNA is positively charged & 1 & 2 & 3 & 4 & 5 \\
\hline $\begin{array}{l}\text { 5. Gel electrophoresis is used to shock the } \\
\text { DNA so it "splits" open. }\end{array}$ & 1 & 2 & 3 & 4 & 5 \\
\hline $\begin{array}{l}\text { 6. Gel electrophoresis allows one to see } \\
\text { the DNA and determine if extraction } \\
\text { was successful }\end{array}$ & 1 & 2 & 3 & 4 & 5 \\
\hline $\begin{array}{l}\text { 7. DNA can be used to determine the } \\
\text { propensities of an organism to disease. }\end{array}$ & 1 & 2 & 3 & 4 & 5 \\
\hline $\begin{array}{l}\text { 8. DNA extraction allows scientists to } \\
\text { determine mutations in a DNA } \\
\text { sequence. }\end{array}$ & 1 & 2 & 3 & 4 & 5 \\
\hline $\begin{array}{l}\text { 9. PCR requires special enzymes to } \\
\text { function at really high temperatures. }\end{array}$ & 1 & 2 & 3 & 4 & 5 \\
\hline $\begin{array}{l}\text { 10. PCR stands for Polymerase Chain } \\
\text { Reaction }\end{array}$ & 1 & 2 & 3 & 4 & 5 \\
\hline 11. DNA can be amplified using PCR & 1 & 2 & 3 & 4 & 5 \\
\hline $\begin{array}{l}\text { 12. It is easy to sequence small amounts of } \\
\text { DNA }\end{array}$ & 1 & 2 & 3 & 4 & 5 \\
\hline $\begin{array}{l}\text { 13. PCR is used to replicate a single or few } \\
\text { copies of DNA. }\end{array}$ & 1 & 2 & 3 & 4 & 5 \\
\hline $\begin{array}{l}\text { 14. PCR is used to isolate only one gene } \\
\text { within a genome. }\end{array}$ & 1 & 2 & 3 & 4 & 5 \\
\hline $\begin{array}{l}\text { 15. PCR is done to make DNA sequencing } \\
\text { easier }\end{array}$ & 1 & 2 & 3 & 4 & 5 \\
\hline $\begin{array}{l}\text { 16. PCR causes cells to replicate } \\
\text { producing more DNA. }\end{array}$ & 1 & 2 & 3 & 4 & 5 \\
\hline $\begin{array}{l}\text { 17. To sequence DNA, dideoxynucleotides } \\
\text { are used. }\end{array}$ & 1 & 2 & 3 & 4 & 5 \\
\hline $\begin{array}{l}\text { 18. DNA is made up of four different } \\
\text { nucleotides }\end{array}$ & 1 & 2 & 3 & 4 & 5 \\
\hline $\begin{array}{l}\text { 19. It is possible to sequence segments of } \\
\text { DNA }\end{array}$ & 1 & 2 & 3 & 4 & 5 \\
\hline $\begin{array}{l}\text { 20. DNA sequencing never works if the } \\
\text { DNA contains mutations }\end{array}$ & 1 & 2 & 3 & 4 & 5 \\
\hline
\end{tabular}


21. DNA Sequencing defines the

$\begin{array}{lllll}1 & 2 & 3 & 4 & 5 \\ 1 & 2 & 3 & 4 & 5\end{array}$

22. Knowing what the DNA sequence is for one gene determines the DNA sequence for the whole organism's genome.

23. The DNA sequence is essential for gene analysis

24. Today DNA Sequencing takes too long to be useful.

25. Computers are used to create the sequences of the DNA.

26. Complimentary base pairing allows us to be able to create DNA sequences.

27. Bioinformatics is using computer programs to analyze DNA

28. Bioinformatics is another name for a biological website.

29. Bioinformatics is a technological application of Biology

30. Bioinformatics is used to compare multiple DNA sequences

31. By knowing the DNA sequences we can know how the genes will be expressed.

32. Bioinformatic Databases have allowed for easier comparison of genomes.

33. Phylogenetic trees are also called cladograms.

34. The same trait can never evolve in unrelated groups.

35. Phylogenetics is the classification and naming of organisms.

36. Phylogenetics shows how organisms relate evolutionarily

37. Phylogenetic mapping is made possible by molecular (DNA) sequencing

38. Phylogenetic trees are used to show evolutionary relationships

39. Phylogenetic trees help biologists understand how species are related.

40. Phylogenetics helps classify species that aren't related to any other species.

\begin{tabular}{|c|c|c|c|c|}
\hline 1 & 2 & 3 & 4 & 5 \\
\hline 1 & 2 & 3 & 4 & 5 \\
\hline 1 & 2 & 3 & 4 & 5 \\
\hline 1 & 2 & 3 & 4 & 5 \\
\hline 1 & 2 & 3 & 4 & 5 \\
\hline 1 & 2 & 3 & 4 & 5 \\
\hline 1 & 2 & 3 & 4 & 5 \\
\hline 1 & 2 & 3 & 4 & 5 \\
\hline 1 & 2 & 3 & 4 & 5 \\
\hline 1 & 2 & 3 & 4 & 5 \\
\hline 1 & 2 & 3 & 4 & 5 \\
\hline 1 & 2 & 3 & 4 & 5 \\
\hline 1 & 2 & 3 & 4 & 5 \\
\hline 1 & 2 & 3 & 4 & 5 \\
\hline 1 & 2 & 3 & 4 & 5 \\
\hline 1 & 2 & 3 & 4 & 5 \\
\hline 1 & 2 & 3 & 4 & 5 \\
\hline 1 & 2 & 3 & 4 & 5 \\
\hline
\end{tabular}


Matrix of test question numbers and what they are asking.

\begin{tabular}{|l|l|l|l|l|l|}
\hline & $\begin{array}{l}\text { DNA } \\
\text { extraction/gel } \\
\text { electrophoresis }\end{array}$ & PCR & $\begin{array}{l}\text { DNA } \\
\text { sequencing }\end{array}$ & Bioinformatics & Phylogenetics \\
\hline Knowledge & $1-5$ & $9-13$ & $17-21$ & $25-29$ & $33-37$ \\
\hline Purpose & $6-8$ & $14-16$ & $22-24$ & $30-32$ & $38-40$ \\
\hline
\end{tabular}

Note: The numbers in the table refer to the question number in the pre and post test.

Teacher Interview Questions

1. Do you feel that your students have a good grasp of the vocabulary presented in the pre and post test?

2. How successful was the intervention? Did all classes have the same level of success?

3. Do you think there would be a difference in how much students learned as the day progressed from first to sixth period?

4. Do you think the test is an appropriate level for the students?

\section{Student Interview Questions}

1. What did you learn about biotechnology through this activity?

2. What new vocabulary did you learn?

3. Do you think most of the students understood the activity?

4. Do you think you would learn more if given the opportunity to do the activity again?

5. Do you find you understood the assessment? 